\title{
High frequency and molecular epidemiology of metallo- $\beta$-lactamase- producing gram-negative bacilli in a tertiary care hospital in Lahore, Pakistan
}

Noor UI Ain ${ }^{1}$, Anam Iftikhar', Syeda Sadia Bukhari ${ }^{1}$, Samyyia Abrar ${ }^{1}$, Shahida Hussain', Muhammad Hayat Haider ${ }^{1}$, Farhan Rasheed ${ }^{2}$ and Saba Riaz ${ }^{1,3^{*}}$

\begin{abstract}
Background: Metallo- $\beta$-lactamase (MBL)-producing isolates have a strong impact on diagnostic and therapeutic decisions. A high frequency of MBL-producing gram-negative bacilli has been reported worldwide. The current study was based on determining the incidence of MBL-producing imipenem-resistant clinical isolates and investigating the $\beta$-lactamase gene variants in strains conferring resistance to a carbapenem drug (imipenem).

Methods: A total of 924 gram negative isolates were recovered from a tertiary care hospital in Lahore, Pakistan, during a two-year period (July 2015 to February 2017). The initial selection of bacterial isolates was based on antibiotic susceptibility testing. Strains resistant to imipenem were processed for the molecular screening of $\beta$-lactamase genes. Statistical analysis for risk factor determination was based on age, gender, clinical specimen and type of infection.
\end{abstract}

Results: The rate of imipenem resistance was calculated to be $56.51 \%$. Among the 142 strains processed, the phenotypic tests revealed that the incidence of MBLs was $63.38 \%$ and $86.61 \%$ based on the combination disc test and the modified Hodge test, respectively. The frequencies of bla $a_{\mathrm{TEM}}, b / a_{\mathrm{SHV}}, b a_{\mathrm{OXA}}, b / a_{\mathrm{IMP}-1}$, and $b / a_{\mathrm{VIM}}$ genes were calculated to be $46 \%$, $34 \%, 24 \%, 12.5 \%$ and $7 \%$, respectively. The co-expression of bla $a_{\mathrm{MBL}}\left(b / a_{\mathrm{IMP}}\right.$ and $\left.b / a_{\mathrm{VIM}}\right)$ and bla $a_{\mathrm{ESBL}}\left(b / a_{\mathrm{TEM}}, b / a_{\mathrm{SHV}}\right.$, bla $\left.a_{\mathrm{OXA}}\right)$ was also detected through multiplex and singleplex PCR. bla $a_{\mathrm{OXA}}$, bla $a_{\text {TEM }}$ and bla $a_{\mathrm{SHV}}$ coexisted in $82 \%$ of the isolates. Co-expression of ESBL and MBL genes was found in 7\% of the isolates.

Conclusion: To our knowledge, this is the first report from Pakistan presenting the concomitant expression of bla $a_{\mathrm{OXA}}$, bla $a_{\mathrm{TEM}}$ and bla $a_{\mathrm{SHV}}$ with bla $a_{\mathrm{IMP}-1}$ and bla $a_{\mathrm{VIM}}$ in MBL-producing gram-negative bacilli.

\section{Background}

Dissemination of life-threatening infections caused by $\beta$-lactamase-producing pathogens is a major setback to antimicrobial therapy. The widespread use of carbapenems has resulted in the emergence of carbapenemases, conferring resistance against carbapenem drugs [1-3]. Resistance to carbapenems is worrisome because of the very limited therapeutic options available to treat resistant infections $[4,5]$. The diverse mechanisms of resistance to

\footnotetext{
* Correspondence: saba.mmg@pu.edu.pk

'Department of Microbiology and Molecular Genetics, University of the Punjab, Lahore 5400, Pakistan

${ }^{3}$ Citilab and Research Center, Lahore, Pakistan

Full list of author information is available at the end of the article
}

imipenem include AmpC enzymes accompanied by membrane porin alterations and upregulation of efflux pumps $[5,6]$. The second phenomenon is carbapenem hydrolysis by carbapenemases [7-9]. The epicentre for the emergence of carbapenemases and that of extended spectrum beta lactamases (ESBLs) were different, but the association of their genes is apparent through some studies, where ESBL genes are found to exist in MBL-producing isolates [10].

Among carbapenemases, metallo- $\beta$-lactamases (MBLs) are of prime importance for the region under study because of the emergence of new variants of MBL, such as New Delhi metallo- $\beta$-lactamase (NDM) [11] and various

(c) The Author(s). 2018 Open Access This article is distributed under the terms of the Creative Commons Attribution 4.0 International License (http://creativecommons.org/licenses/by/4.0/), which permits unrestricted use, distribution, and reproduction in any medium, provided you give appropriate credit to the original author(s) and the source, provide a link to the Creative Commons license, and indicate if changes were made. The Creative Commons Public Domain Dedication waiver (http://creativecommons.org/publicdomain/zero/1.0/) applies to the data made available in this article, unless otherwise stated. 
IMP variants from the subcontinent. MBLs belong to class B carbapenemases according to the Ambler classification system [12]. bla $a_{\mathrm{IMB}}$ bla $a_{\mathrm{NDM}}$ and $b l a_{\mathrm{VIM}}$ are important MBL gene clusters that are carried by mobile plasmids compatible with a vast array of clinically important pathogens $[13,14]$. In addition, oxacillinases belonging to class $\mathrm{D}$ include serine $\beta$-lactamases and are known to be associated primarily with Enterobacteriaceae carbapenem-resistant epidemics.

With more than 37 types of IMP carbapenemases known [15], IMP-1 was the first to be reported in Japan in 1991[16]. IMP-4-type enzymes, first discovered in Hong Kong during the 2000s [17], were later found to be responsible for an outbreak in 2005 in Melbourne, Australia [18]. The dissemination of resistance genes from Serratia spp. and Pseudomonas aeruginosa to other members of Enterobacteriaceae caused these genes to become endemic in Australia. Approximately 20 different subtypes of IMP enzymes have been described to be associated with Pseudomonas spp., Acinetobacter spp. and Enterobacteriaceae infections throughout the globe [19].

The first case of VIM-1 enzyme-conferred resistance was reported in 1999 in Verona, Italy [20]. With reports of VIM-2 being highly prevalent in Europe, Asia, America and Africa [21], a recent global surveillance study reported four new variants of VIM [22]. After their discovery in New Delhi in 2009 [23], NDM-1-producing Klebsiella pneumoniae and E. coli have been widely reported throughout the globe, including various European countries as well as China, Kenya, Japan, Algeria and Syria [24-27]. A research study has indicated dissemination of the NDM-1 carbapenemase gene through horizontal gene transfer in Pakistan, India and the UK [28].

The rise in carbapenem resistance in Asian countries has been evident, as reported imipenem resistance rose from $20 \%$ in the Philippines [29] to $40 \%$ in Vietnam [30]. Recently, > 50\% carbapenem-resistant Klebsiella pneumoniae isolates have been recorded in India [31]. With the first report of emergence among Acinetobacter baumannii clinical isolates in Scotland in 1985 [32], plasmid-borne OXA-48 carbapenemases were reported to be highly disseminated in isolates from 18 countries in Europe and Africa [33].

The resistance pattern of metallo- $\beta$-lactamases in Pakistan has not been widely studied. In Pakistan, imipenem was only rarely available prior to the year 2000 [34]. Later, carbapenem resistance was reported mainly in $P$. aeruginosa in Lahore and Karachi [35, 36]. A report from Rawalpindi confirmed that $78 \%$ of isolates were MBL producers, with major incidence of MBL production in Acinetobacter baumannii and Pseudomonas aeruginosa [37].

A very limited number of reports have been published from Pakistan that are based on molecular analysis of genes acquired by carbapenem-resistant isolates. This study aimed to determine the incidence of MBLs through phenotypic and genotypic analyses. Moreover, this study is based on the detection of the gene variants responsible for resistance to carbapenem drugs. To the best of our knowledge, this is the first study from Lahore on the molecular epidemiology and coexistence of $b l a_{\mathrm{ESBLs}}$ and $b l a_{\mathrm{MBL} s}$.

\section{Methods}

\section{Study design}

Microbiological testing was conducted at the pathology laboratory of Allama Iqbal Medical College Lahore from July 2015 to July 2017 . The study was approved by the Ethical Committee of Citilab and Research Centre Pakistan (CitiLab and Research Centre Ref \# 30th - 15 CLRC/ 30th). The segment of the work based on molecular analysis was carried out at the Department of Microbiology and Molecular Genetics, University of the Punjab, Lahore.

\section{Bacterial isolates}

A total of 3000 samples were obtained from clinical samples. All clinical specimens were subjected to isolation and identification of significant pathogens according to CLSI procedures (CLSI 2015, 2016). Among 2000 cultures with positive growth, 924 gram negative isolates bacilli were further screened for acquisition of imipenem resistance. On the basis of antibiotic susceptibility patterns, 142 isolates resistant to imipenem were further analysed by molecular tools. Identification of bacterial isolates was performed on the basis of culture characteristics, gram staining and conventional biochemical tests. Confirmation of gram-negative isolates was performed by API $20 \mathrm{NE}$ identification strips (bioMerieux, France). The identified strains were stored in $30 \%$ glycerol broth at $-70{ }^{\circ} \mathrm{C}$. Isolates were obtained from wound infections $(n=487)$, urine samples $(n=187)$, sputum samples $(n=90)$, tips and catheters $(n=47)$, fluids and effusions $(n=44)$ and others, including tissue samples, bone samples, and vaginal swabs $(n=57)$ (Table 3).

\section{Antimicrobial susceptibility testing}

Antimicrobial susceptibility testing (AST) for all isolates was carried out by the Kirby-Bauer method [38] on Mueller-Hinton agar plates (Oxoid) as per Clinical and Laboratory Standard Institute (CLSI, 2016) recommendations. The antibiotic panel used in screening of the cultures was specific for gram-negative bacteria: penicillins (amoxicillin $30 \mu \mathrm{g}$, amoxicillin-clavulanic acid $40 \mu \mathrm{g}$, and piperacillin-tazobactam $30 \mu \mathrm{g}$ ), monobactam (aztreonam $30 \mu \mathrm{g}$ ), extended-spectrum cephalosporins (ceftriaxone $30 \mu \mathrm{g}$, cefepime $30 \mu \mathrm{g}$, cefotaxime $30 \mu \mathrm{g}$, cefoxitin $30 \mu \mathrm{g}$, and ceftazidime $30 \mu \mathrm{g})$, carbapenems (imipenem $30 \mu \mathrm{g}$ ), aminoglycosides (amikacin $30 \mu \mathrm{g}$ and gentamicin $30 \mu \mathrm{g}$ ), quinolone (ciprofloxacin $30 \mu \mathrm{g}$ ) 
and trimethoprim-sulfamethoxazole $(40 \mu \mathrm{g})$. The results of the susceptibility testing were used to calculate the multiple antibiotic resistance (MAR) index for the clinical isolates in order to estimate drug resistance trends and the emergence of new resistant isolates.

\section{Phenotypic detection of MBLs}

Phenotypic detection of MBLs was based on three tests according to the CLSI guidelines (2015-2016). The combination disc test, using a disc of imipenem and imipenem with incorporated EDTA, was performed as per the method used by Wadekar, Anuradha [39]. A modified Hodge test (MHT) was performed according to the method used by Kumar et al. [40]. The results for each type of isolate were interpreted according to the criteria defined in CLSI 2016. All antibiotics were obtained from Oxoid, Inc. (Canada). E-strips with IMI and IMP/EDTA were used for epsilometer confirmation of MBLs according to the manufacturer's instructions (Liofilchem ${ }^{\circ}$ ).

\section{Molecular characterization of MBLs DNA template preparation for PCR}

The template DNA was extracted from isolates using previously described methods [41]. Briefly, a single colony of bacterial isolate was immersed in low TE, and the suspension was boiled for $10 \mathrm{~min}$. The bacterial cell emulsion was centrifuged, and DNA in the supernatant was directly used as a template for PCR amplification.

\section{Detection of ESBL and MBL genes}

All of the positive MBL isolates based on phenotypic detection $(n=123)$ were further confirmed by singleplex and multiplex colony PCR. Multiplex PCR for $b l a_{\mathrm{TEM}}, b l a_{\mathrm{OXA}}$ and $b l a_{\mathrm{SHV}}$ detection was devised. The primer sequences used for the detection of $b l a_{\mathrm{TEM}}, b l a_{\mathrm{OXA}}$ and $b l a_{\mathrm{SHV}}$ genes have been previously reported [42]. Screening for isolates having the $b l a_{\mathrm{IMP}-1}$ gene and $b l a_{\mathrm{VIM}}$ gene was performed by singleplex PCR using previously reported primers $[43$, 44]. The PCR reaction was set up with a $25 \mu \mathrm{l}$ mixture containing 10X PCR buffer, $2.5 \mathrm{mM}$ mixture of dNTPs, 20 pmol each primer and $2.5 \mathrm{U}$ of Taq polymerase. The amplification conditions were set with an initial denaturation at $95{ }^{\circ} \mathrm{C}$ proceeded by 35 cycles of 1 min denaturation at $95{ }^{\circ} \mathrm{C}, 1.5 \mathrm{~min}$ annealing (temperatures mentioned in Table 1), extension for $1 \mathrm{~min}$ and final extension for $10 \mathrm{~min}$ at $72{ }^{\circ} \mathrm{C}$. The $\mathrm{Mg}$ concentration was maintained between 1 and $1.5 \mathrm{mM}$.

\section{Statistical analysis}

The collected demographic data were statistically analysed using the Statistical Package for Social Sciences (SPSS version 23). The proportions of Acinetobacter spp., Pseudomonas spp. and members of Enterobacteriaceae were calculated using the chi-square test and odds ratios (ORs). A $p$ value of $<0.05$ was considered statistically significant. The associations among the type of infection, age, gender and type of isolate were calculated.

\section{Results}

\section{Distribution of clinical isolates}

In this study, the resistance pattern of imipenem-resistant clinical isolates was assessed, and the incidence of MBL production among these isolates was determined. Moreover, the significant gene variants associated with the MBL phenotype were analysed. Demographic factors and sites of infection were major highlights of the statistical data analysis. Out of a total of 942 isolates, the total frequency of imipenem resistance was calculated to be $56.512 \%(n=512)$. The highest resistance to imipenem was observed for Acinetobacter spp., at $61.89 \%$. Pseudomonas spp. ranked second in terms of the acquisition of imipenem resistance, with a frequency of $61.89 \%$, followed by Klebsiella spp. (50.26\%) and Escherichia coli (37.97\%). Males were found to be more prone to the acquisition of imipenem-resistant infections $(60.69 \%)$ compared to females (39.31\%). The infectivity rates varied between different age groups, with the maximum mean observed among individuals of the age group 2040 years. The mean age of individuals acquiring MBL infection was 30 years. Wound infections were found to be the most dominant type of infection (51.70\%), followed by urinary tract infections (19.86\%), respiratory

Table 1 List of the Primers used for the detection of ESBL-Type variant (b/a $a_{\mathrm{OXA}}, b_{a_{\mathrm{TEM}}}$ and $b / a_{\mathrm{SHV}}$ and MBL-type variants (bla $a_{\mathrm{MP}-1}$ and bla $\left.a_{\mathrm{VIM}}\right)$

\begin{tabular}{|c|c|c|c|c|}
\hline Primers & Sequences & Annealing temperature $\left(\mathrm{Tm}^{\circ} \mathrm{C}\right)$ & References & Expected PCR product \\
\hline bla $a_{M P-1}$ & $\begin{array}{l}\text { AGCGCAGCATATTGATTGC } \\
\text { ACAACCAGATGCTGCCTTACC }\end{array}$ & 53.6 & [43] & 587 \\
\hline$B l a_{\mathrm{VIM}}$ & $\begin{array}{l}\text { ATGGTCGTTATGGCATATC } \\
\text { TGGGCCGTGTCAGCCAGAT }\end{array}$ & 57 & [44] & 510 \\
\hline$B l a_{\mathrm{TEM}}$ & $\begin{array}{l}\text { CCCCGAAGAAGTCCTITC } \\
\text { ATCAGCAATAGTCCCAGC }\end{array}$ & 55 & [42] & 500 \\
\hline$B l a_{\mathrm{SHV}}$ & $\begin{array}{l}\text { AGGGCTTGACTGCCATTTTG } \\
\text { ATTGCGTGATTCATTा }\end{array}$ & 55 & {$[42]$} & 400 \\
\hline$B l a_{\mathrm{OXA}}$ & $\begin{array}{l}\text { ATATCTCGCTTGTTGCATCTCC } \\
\text { AAACCCTTCAGCTCATCC }\end{array}$ & 55 & [42] & 600 \\
\hline
\end{tabular}


tract infections (9.6\%), and infections associated with indwelling catheters (5.2\%).

\section{Antibiotic susceptibility testing of $\mathrm{MBL}$ isolates}

The panel of antibiotics recommended according to CLSI 2016 guidelines was applied for all isolates belonging to Enterobacteriaceae, Pseudomonas spp. and Acinetobacter spp. Escherichia coli and Klebsiella spp. exhibited susceptibility to gentamycin and piperacillin-tazobactam (23\%), amikacin (16\%) and sulfamethoxazole/trimethoprim (15\%). All the generations of cephalosporins, carbapenem and monobactams showed a complete resistance pattern. Pseudomonas spp. and Acinetobacter spp. presented susceptibility to amikacin and aztreonam (12\%), piperacillintazobactam (8\%), sulfamethoxazole/trimethoprim and gentamycin (7\%) and ciprofloxacin (3\%). Multiple antibiotic resistance (MAR) index values for $>50 \%$ of the isolates fell in the range of $0.81-1.00$, and $86 \%$ of the Pseudomonas spp. isolates fell in the range of 0.91-1.0. E. coli predominantly had a MAR index value of $0.91-1$. A total of $75 \%$ of the Klebsiella spp. isolates had a MAR index value ranging between 0.81 and 1 .

\section{Phenotypic detection of MBLs}

Out of the 906 isolates analysed, 142 randomly selected isolates were suspected to produce metallo- $\beta$-lactamases. Among these isolates, $63.38 \%(n=90)$ revealed a positive combination disc test, whereas $36.61 \%(n=52)$ remained non-determinable by CDST. A total of $86.61 \%(n=123)$ of the isolates were confirmed to be MBL producers through the modified Hodge test with meropenem. However, the modified Hodge test with imipenem detected $78.17 \%(n=111)$ of the isolates as positive for MBL production and $22.53 \%(n=32)$ as negative for MBL production. A total of $68 \%(n=96 \%)$ of the strains were confirmed to exhibit the MBL phenotype through the epsilometer test (E-test).

Multiplex PCR for bla $a_{\mathrm{OXA}}, b l a_{\mathrm{TEM}}, b l a_{\mathrm{SHV}}, b l a_{\mathrm{IMP}}$ and $b l a_{\mathrm{VIM}}$ The presence of $b l a_{\mathrm{OXA}}, b l a_{\mathrm{TEM}}$ and $b l a_{\mathrm{SHV}}$ genes was confirmed in $57.74 \%(n=82 \%)$ of MBL-producing strains by multiplex PCR. The existence of the bla $a_{\text {TEM }}$ gene in MBL-producing isolates was found to be the most prevalent, at $46 \%$, followed by the bla ${ }_{\mathrm{SHV}}$ gene $(34 \%)$ and $b l a_{O X A}$ gene (24\%). bla $a_{\mathrm{IMP}-1}$ and bla ${ }_{V I M}$ genes were detected in $12.5 \%(n=18)$ and $7 \%(n=10)$ of strains, respectively. The coexistence of all these genes was determined by multiplex PCR. In total, 60\% (49/82) of the MBL-positive strains were found to have the $b l a_{\mathrm{OXA}}$, $b l a_{\mathrm{TEM}}$ and $b l a_{\mathrm{SHV}}$ genes in coexistence with each other. The bla $a_{\text {TEM }}$ gene was found to coexist with bla $a_{O X}$-type variants in $21 \%(n=30)$ of the MBL producers. The combination of $b l a_{\mathrm{TEM}}$ and $b l a_{\mathrm{SHV}}$ was detected to be the most common, as exhibited by $24 \%$ of the strains. The coexistence of $b l a_{\mathrm{OXA}}$ and $b l a_{\mathrm{SHV}}$ genes was observed in $12 \%$ of the total isolates. The three genes blaTEM, bla $a_{\mathrm{OXA}}$ and $b l a_{\mathrm{SHV}}$ were found to coexist in $9 \%$ of the strains (Fig. 1).

\section{Statistical analysis}

Statistical analysis was performed with SPSS version 23.0 individually for all groups of isolates, including Escherichia coli, Klebsiella spp., Acinetobacter spp. and Pseudomonas spp. (Table 2). The associations among demographic variables, including age, gender and type of infections, were determined by calculating odd ratios and performing the chi-square test. A $p$-value of $<0.05$ was considered statistically significant (Tables 2, 3, 4).

\section{Discussion}

Pakistan is a country where empirical drug therapy and misuse of antibiotics are common practice. Poor sanitation, filthy practices in clinical settings, and ill-informed health care workers are factors in the dissemination of nosocomial pathogensto the community. Routinely used second-generation drugs are quickly being replaced by drugs of last resort, and this situation is ultimately an enduring threat to mankind. According to one estimate, first-line antibiotic-resistant pathogens account for 25,692 neonatal deaths annually in Pakistan [45]. Resistance to carbapenems has been significantly observed in Asian countries, including Pakistan [30, 46, 47]. At

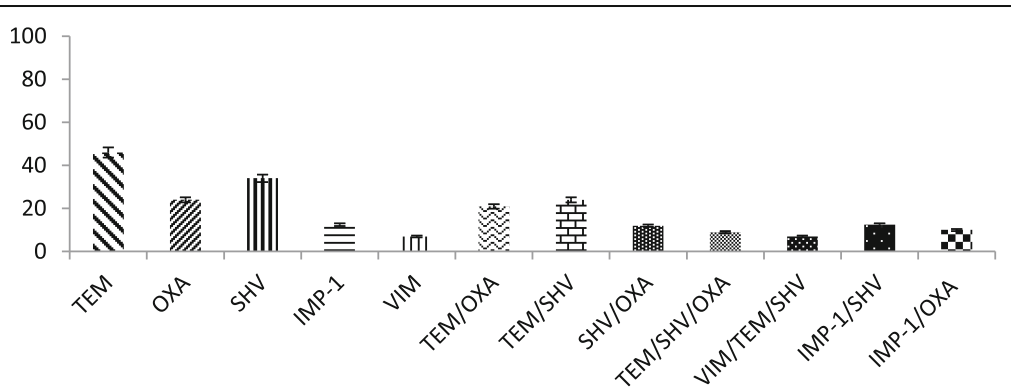

Fig. 1 Frequencies of different gene variants (TEM, SHV, OXA, VIM, IMP) in MBL producing clinical isolates. The presence of genes bla ${ }_{\mathrm{OXA}}$, bla bla $a_{\mathrm{SHV}}$ bla $a_{\mathrm{IMP}-1}$ and bla $\mathrm{VIM}_{\mathrm{M}}$ was detected in MBL strains through PCR 
Table 2 Comparison of Carbapenem resistant isolates between different age groups

\begin{tabular}{|c|c|c|c|c|c|c|}
\hline \multirow{2}{*}{$\begin{array}{l}\text { Age } \\
\text { (years) }\end{array}$} & \multirow{2}{*}{$\begin{array}{l}\text { No. of } \\
\text { Isolates }\end{array}$} & \multicolumn{2}{|l|}{ Imipenem } & \multirow{2}{*}{$\begin{array}{l}\text { Chi } \\
\text { value }\end{array}$} & \multirow[t]{2}{*}{ OR $(95 \% \mathrm{Cl})$} & \multirow{2}{*}{$\begin{array}{l}p \text { - } \\
\text { value }\end{array}$} \\
\hline & & $R$ & $S$ & & & \\
\hline \multicolumn{7}{|c|}{ Escherchia coli } \\
\hline $1-9$ & 5 & $4(80 \%)$ & $1(20 \%)$ & - & $2.28[0.23-22.87]$ & 0.643 \\
\hline 10-19 & 7 & $4(57.14 \%)$ & $3(42.85 \%)$ & & $0.758[0.157-3.66]$ & 0.704 \\
\hline $20-29$ & 38 & $15(39.47 \%)$ & $23(60.52 \%)$ & 10.10 & 0.317 [0.153-0.657] & 0.001 \\
\hline $30-39$ & 29 & $9(31.03 \%)$ & $20(68.96 \%)$ & 7.85 & 0.308 [0.132-0.723] & 0.005 \\
\hline $40-49$ & 34 & $13(38.23 \%)$ & $21(61.76 \%)$ & 2.45 & $0.537[0.245-1.176]$ & 0.117 \\
\hline $50-59$ & 32 & $11(34.37 \%)$ & $21(65.62 \%)$ & 4.58 & $0.414[0.182-0.940]$ & 0.032 \\
\hline $60-69$ & 26 & $8(30.76 \%)$ & $18(69.23 \%)$ & 5.69 & $0.316[0.120-0.831]$ & 0.017 \\
\hline $70-79$ & 9 & $5(55.55 \%)$ & $4(44.44 \%)$ & - & $0.809[0.177-3.69]$ & 1.000 \\
\hline$>79$ & 7 & $2(28.57 \%)$ & $5(71.42 \%)$ & - & 0.150 [0.018-1.237] & 0.145 \\
\hline \multicolumn{7}{|c|}{ Acinetobacter spp. } \\
\hline $1-9$ & 11 & $8(66.66 \%)$ & $4(33.33 \%)$ & 1.252 & $1.8[0.638-5.072]$ & 0.999 \\
\hline $10-19$ & 25 & $18(72 \%)$ & $7(28 \%)$ & 3.14 & $2.015[0.92-4.41]$ & 0.264 \\
\hline $20-29$ & 39 & $29(74.35 \%)$ & $10(25.64 \%)$ & 8.05 & 2.94 [1.37-6.33] & 0.076 \\
\hline $30-39$ & 42 & $31(73.80 \%)$ & $11(26.19 \%)$ & 0.56 & 1.33 [0.633-2.79] & 0.004 \\
\hline $40-49$ & 38 & $21(55.26 \%)$ & 17 (44.74\%) & 6.18 & 2.94 [1.28-6.73] & 0.451 \\
\hline $50-59$ & 34 & $24(70.58 \%)$ & $10(29.41 \%)$ & - & 3.87 [1.26-11.81] & 0.009 \\
\hline $60-69$ & 20 & $15(75 \%)$ & $5(25 \%)$ & - & $1.031[0.23-4.53]$ & 0.026 \\
\hline $70-79$ & 10 & $6(60 \%)$ & $4(40 \%)$ & - & & 0.999 \\
\hline$>79$ & 4 & $4(100 \%)$ & $0(0 \%)$ & & & \\
\hline \multicolumn{7}{|c|}{ Klebsiella spp. } \\
\hline $1-9$ & 11 & $6(54.54 \%)$ & $5(45.45)$ & 0.870 & 0.505 [0.119-2.145] & 0.351 \\
\hline $10-19$ & 10 & $6(60 \%)$ & $4(40 \%)$ & - & $0.857[0.220-3.343]$ & 1.000 \\
\hline $20-29$ & 40 & $22(55 \%)$ & $18(45 \%)$ & 1.040 & $0.695[0.345-1.401]$ & 0.824 \\
\hline $30-39$ & 41 & $19(46.34 \%)$ & $22(53.65 \%)$ & 1.52 & 0.645 [0.320-1.299] & 0.218 \\
\hline $40-49$ & 26 & $15(57.69 \%)$ & $11(42.30 \%)$ & 0.749 & 1.458 [0.619-3.43] & 0.387 \\
\hline $50-59$ & 26 & $8(30.76 \%)$ & $18(69.23 \%)$ & 5.230 & $0.356[0.143-0.883]$ & 0.022 \\
\hline $60-69$ & 19 & $9(47.36 \%)$ & $10(52.63)$ & 0.097 & 0.851 [0.309-2.343] & 0.755 \\
\hline $70-79$ & 11 & $8(72.72 \%)$ & $3(27.27 \%)$ & - & $2.286[0.493-10.605]$ & 0.466 \\
\hline$>79$ & 5 & $2(40 \%)$ & $3(60 \%)$ & - & $0.417[0.051-3.435]$ & 0.608 \\
\hline \multicolumn{7}{|c|}{ Pseudomonas spp. } \\
\hline $1-9$ & 9 & $6(66.67 \%)$ & $3(33.34 \%)$ & - & $1.05[0.22-5.13]$ & 1.000 \\
\hline $10-19$ & 34 & $20(58.83 \%)$ & $14(41.17 \%)$ & 0.497 & $0.71[0.28-1.82]$ & 0.481 \\
\hline $20-29$ & 75 & 54 (72\%) & $21(28 \%)$ & 5.093 & $2.02[1.09-3.74]$ & 0.024 \\
\hline $30-39$ & 61 & 38 (62.29\%) & $23(37.70 \%)$ & 2.127 & $1.59[0.85-3.00]$ & 0.145 \\
\hline $40-49$ & 44 & $23(52.27 \%)$ & 21 (47.72) & 0.130 & $1.14[0.56-2.31]$ & 0.718 \\
\hline $50-59$ & 51 & $30(58.83 \%)$ & 21 (41.17\%) & 1.917 & $1.63[0.81-3.25]$ & 0.166 \\
\hline $60-69$ & 25 & $14(56 \%)$ & $11(44 \%)$ & 0.410 & $1.35[0.54-3.41]$ & 0.522 \\
\hline $70-79$ & 6 & $3(50 \%)$ & $3(50 \%)$ & - & $0.63[0.11-3.66]$ & 0.670 \\
\hline$>79$ & 2 & $2(100 \%)$ & 0 & - & - & 0.477 \\
\hline
\end{tabular}


Table 3 Association of imipenem resistant isolates with type of clinical specimens

\begin{tabular}{|c|c|c|c|c|c|c|c|}
\hline \multirow[t]{2}{*}{ Isolate } & \multirow[t]{2}{*}{ Sample } & \multirow[t]{2}{*}{$(N)$} & \multicolumn{2}{|c|}{ Imipenem } & \multirow{2}{*}{$\begin{array}{l}\text { Chi } \\
\text { value }\end{array}$} & \multirow[t]{2}{*}{ OR } & \multirow[t]{2}{*}{$p$-value } \\
\hline & & & $\mathrm{R}$ & $S$ & & & \\
\hline \multirow[t]{6}{*}{ Escherichia coli } & Wound & 65 & 22 & 43 & 23.013 & $0.276[0.159-0.478]$ & 0.000 \\
\hline & Fluids \& Effusion & 13 & 3 & 10 & - & $0.123[0.027-0.553]$ & 0.007 \\
\hline & Tips \& Catheters & 6 & 5 & 1 & - & $1.833[0.192-17.48]$ & 1.00 \\
\hline & Urine & 79 & 34 & 45 & 0.894 & $0.756[0.422-1.351]$ & 0.344 \\
\hline & Sputum & 12 & 5 & 7 & 0.096 & $0.824[0.242-2.806]$ & 0.757 \\
\hline & Others & 14 & 4 & 10 & - & $0.403[0.290-0.559]$ & 0.070 \\
\hline \multirow[t]{6}{*}{ Acinetobacter spp. } & Wound & 130 & 92 & 38 & 7.16 & 1.79 [1.16-2.75] & 0.006 \\
\hline & Fluids \& Effusion & 13 & 11 & 2 & - & $6.67[1.26-35.28]$ & 0.021 \\
\hline & Tips \& Catheters & 22 & 17 & 5 & 0.171 & $1.32[0.35-4.97]$ & 0.679 \\
\hline & Urine & 21 & 11 & 10 & 0.265 & $1.27[0.51-3.15]$ & 0.606 \\
\hline & Sputum & 25 & 15 & 10 & 2.73 & $2.17[0.85-5.50]$ & 0.098 \\
\hline & Others & 13 & 10 & 3 & - & $4.38[1.05-18.17]$ & 0.056 \\
\hline \multirow[t]{6}{*}{ Klebsiella spp. } & Wound & 71 & 43 & 28 & 0.004 & 0.983 [0.59-1.64] & 0.947 \\
\hline & Fluids \& Effusion & 11 & 6 & 5 & 0.031 & $0.88[0.22-3.49]$ & 0.861 \\
\hline & Tips \& Catheters & 10 & 7 & 3 & - & $0.75[0.16-3.52]$ & 0.700 \\
\hline & Urine & 58 & 25 & 33 & 0.534 & $0.79[0.43-1.48]$ & 0.465 \\
\hline & Sputum & 30 & 13 & 17 & 0.110 & $0.86[0.36-2.06]$ & 0.740 \\
\hline & Others & 10 & 4 & 6 & - & $0.59[0.15-2.35]$ & 0.504 \\
\hline \multirow[t]{6}{*}{ Pseudomonas spp. } & Wound & 221 & 142 & 79 & 1.84 & 1.29 [0.89-1.85] & 0.174 \\
\hline & Fluids \& Effusion & 7 & 5 & 2 & - & $2.12[0.36-12.38]$ & 0.680 \\
\hline & Tips \& Catheters & 9 & 6 & 3 & - & 0.62 [0.13-2.99] & 0.674 \\
\hline & Urine & 29 & 19 & 10 & 4.669 & $2.44[1.06-5.58]$ & 0.031 \\
\hline & Sputum & 23 & 9 & 14 & 0.547 & $0.69[0.27-1.81]$ & 0.459 \\
\hline & Others & 20 & 11 & 9 & 0.210 & $1.29[0.43-3.84]$ & 0.647 \\
\hline
\end{tabular}

${ }^{*}$ OR Odd ratio\& ${ }^{* *} p$ value $<0.05$ is considered as statistically significant

present, numerous reports of MBL producers and ESBL producers from Pakistan present clinical catastrophes and alarming health issues [41, 48, 49]. The present study demonstrates the frequency of imipenem resistance among clinical isolates and the incidence of MBLS producers associated with imipenem resistance in connection with various demographic factors and types of infection. The frequency of imipenem resistance in our study was $56 \%$, which is significantly higher than the data reported from Asian countries in the last decade (2002-2012), with one epidemiological study reporting $1.9 \%$ resistance to imipenem and $2.4 \%$ resistance to meropenem [4].

Table 4 Comparison of infection rate between male and female

\begin{tabular}{|c|c|c|c|c|c|c|c|}
\hline \multirow[t]{2}{*}{ Isolates } & \multirow[t]{2}{*}{ Gender } & \multirow[t]{2}{*}{$(N)$} & \multicolumn{2}{|c|}{ Imipenem } & \multirow{2}{*}{$\begin{array}{l}\text { Chi } \\
\text { value }\end{array}$} & \multirow[t]{2}{*}{$O R^{*}$} & \multirow[t]{2}{*}{$p$-value } \\
\hline & & & $R$ & $S$ & & & \\
\hline \multirow[t]{2}{*}{ Escherichia coli } & Male & 106 & 41 & 65 & 0.0067 & $1.025[0.57-1.85]$ & 0.934 \\
\hline & Female & 84 & 32 & 52 & & & \\
\hline \multirow[t]{2}{*}{ Acinetobacter spp. } & Male & 136 & 94 & 42 & 41.05 & 4.51 [2.81-7.24] & 0.0001 \\
\hline & Female & 90 & 63 & 127 & & & \\
\hline \multirow[t]{2}{*}{ Klebsiella spp. } & Male & 97 & 57 & 40 & 4.67 & 1.87 [1.058-3.328] & 0.03 \\
\hline & Female & 95 & 41 & 54 & & & \\
\hline \multirow[t]{2}{*}{ Pseudomonas spp. } & Male & 203 & 125 & 78 & 0.0017 & $0.98[0.61-1.59]$ & 0.483 \\
\hline & Female & 110 & 68 & 42 & & & \\
\hline
\end{tabular}


Comparison of the antibiotic resistance profiles of all the pathogens with those reported in other recent studies has revealed relatively similar patterns. The resistance pattern of Acinetobacter spp. to imipenem in our study (61.89\%) is in conformity with reports by Anwar et al., but a lower rate $(77.5 \%)$ of imipenem resistance in this region was reported by Shamim et al. [50]. Acinetobacter spp., the pathogen renowned for hospital-acquired infections, was predominantly found to be associated with wound infections and was the causative agent of $92 \%$ infections associated with imipenem resistance. Pseudomonas spp. was the second most prominent pathogen associated with the acquisition of imipenem resistance, with a frequency of $61.89 \%$, and has been noted in other reports from Pakistan, presenting imipenem resistance rates of $13.42 \%$ in 2011 and of $28 \%$ and $49.5 \%$ in 2015 , thus demonstrating a sharp rise in the frequency of imipenem resistance $[49,51,52]$. The victims of Pseudomonas spp. infections were found predominantly in the group of patients with post-burn infections. This finding is in conformity with studies on invasive burn wound infections that document $P$. aeruginosa as a leading pathogen among gram-negative organisms [53, 54]. Wound infections were particularly found to be associated with Acinetobacter spp. (OR $=1.79$ [1.16-2.75]) and Pseudomonas spp. " $\mathrm{OR}=1.29$ [0.89-1.85]).

The incidence of MBL among imipenem-resistant Acinetobacter spp. was calculated to be $89 \%$, which is comparable to that reported in a study by Anwar et al., presenting a frequency of $83.3 \%$ MBLs among carbapenem-resistant isolates [55]. A total of $78 \%$ of the imipenem-resistant Pseudomonas spp. isolates were detected to be MBL producers by the MHT test, representing a lower incidence compared to the study by Shan et al. that stated the incidence rate to be $87.5 \%$ [49].

Our study demonstrates the OXA-type variants to be predominantly associated with resistance to imipenem. All of the isolates harbouring $b l a_{\mathrm{IMP}}$ were also found to harbour $b l a_{\text {TEM }}$. Despite the uncommon origin of two major groups of $\beta$-lactamases, bla $a_{\mathrm{ESBL}}$ and $b l a_{\mathrm{MBL}}$, their association is imminent according to recent research [10]. We analysed the isolates for the coexistence of MBL-type and ESBL-type variants. The $b l a_{\mathrm{VIM}}$ gene variant for MBL production was also found to be in coexistence with blaTEM and bla $a_{\mathrm{SHV}}$ in Providencia stuartii and Enterobacter spp. A total of $12.5 \%$ isolates were found to coexhibit the $b l a_{\mathrm{IMP}-1}$ and $b l a_{\mathrm{SHV}}$ genes, whereas $10 \%$ were positive for the $b l a_{O X A}$ gene along with the $b l a_{\mathrm{IMP}-1}$ gene.

The abovementioned mechanism of coexistence of genes has been reported in Klebsiella pneumoniae, Escherichia coli, Salmonella spp. and Enterobacter spp. [56]. Plasmids containing the $b l a_{\mathrm{NDM}-1}$ gene have been observed to coexhibit genes for CTX-M, TEM-1 and OXA-1 enzymes. Major ESBL and MBL genes, including $b l a_{\mathrm{CTX}-\mathrm{M}}, b l a_{\mathrm{SHV}}, b l a_{\mathrm{TEM}}$, and $b l a_{\mathrm{OXA}-51}$, and genes for the VIM-family and IMP-family, have been reported to coexist in clinically resistant Acinetobacter baumannii in Iran [57]. However, one study concluded that there was no significant relationship between ESBL and MBL production genes [57]. Ertapenem-resistant, ESBL-producing Klebsiella pneumoniae isolates have been reported in Italy and shown to carry novel porin variants that contributed to the reduced susceptibility of isolates to meropenem and imipenem [58].

The coexistence of the genes for MBL and ESBL variants in our isolates indicates the simultaneity of the emergence of different variants of $\beta$-lactamases among pathogens in our clinical settings. This finding also suggests that the resistance against imipenem in our isolates is mediated by MBL-type enzymes along with the overproduction of ESBL-type enzymes, as suggested by other studies $[5,7]$. To the best of our knowledge, this is the first study from Pakistan reporting the coexistence of $b l a_{\text {IMP }}$ with $b l a_{\text {TEM }}$-type and $S H V$-type variants. None of the isolates was found to coexhibit all the tested genes (bla $a_{\mathrm{OXA}}, b l a_{\mathrm{TEM}}, b l a_{\mathrm{SHV}}, b l a_{\mathrm{IMP}-1}$ and $\left.b l a_{\mathrm{VIM}}\right)$.

\section{Conclusion}

In conclusion, ESBL- and MBL-producing bacterial isolates are emerging very rapidly in the region. A great number of carbapenem-resistant clinical bacterial species are resistant to most of the commonly used antibiotics, demonstrating the rise of super-bacteria and their pan-resistance to antimicrobial therapy. Determining the resistance mechanisms and the root cause for their elimination are of great importance. It is also important to implement the routine screening of ESBLs and MBLs in laboratory procedures before antibiotic therapy begins. Further studies are required to specify other types of gene variants prevalent among clinical isolates in our region for the implication of medication in clinical settings.

\section{Abbreviations}

CDST: Combination disc test; DDST: Double disc synergy test; E test: Epsilometer test; ESBLs: Extended-spectrum $\beta$-lactamase-producing strains; ESBLs: Extendedspectrum $\beta$-lactamases; MBLs: Metallo- $\beta$-lactamases; MDR: Multidrug-resistant; MIC: Minimum inhibitory concentration

\section{Acknowledgements \\ This work was funded by the Department of Microbiology and Molecular Genetics, University of the Punjab. The project was established in collaboration with Allama Iqbal Medical College, Lahore, for sample and data collection. The efforts of Mr. Muhammad Umar Farooq, Biostatistician \& Incharge IT, Institute of Public Health (IPH), Lahore, is highly acknowledged for his efforts in performing the data analysis. The authors would like to thank Dr. Muhammad Faisal, CEO of Citilab and the research centre, for his valuable and collaborative suggestions.}

Funding

No funding was received for this study.

Availability of data and materials

The data sets analysed during the current study are available from the corresponding author. 


\section{Declaration}

This study is part of the Ph.D. thesis of Noor-Ul-Ain.

\section{Authors' contributions}

NUA, SR, and FR designed the study. NUA, Al, SSB and SH performed the experimental work. $\mathrm{Al}, \mathrm{SSB}$, and $\mathrm{MHH}$ collected the data. NUA, SA, and $\mathrm{MHH}$ analysed the data. All authors read and approved the final manuscript.

\section{Ethics approval and consent to participate}

The study was approved by the local ethics committee (CitiLab and Research Centre Ref \# 30th - 15 CLRC/ 30th).

\section{Consent for publication}

Not applicable.

\section{Competing interests}

The authors declare that they have no competing interests.

\section{Publisher's Note}

Springer Nature remains neutral with regard to jurisdictional claims in published maps and institutional affiliations.

\section{Author details}

'Department of Microbiology and Molecular Genetics, University of the Punjab, Lahore 5400, Pakistan. ${ }^{2}$ Department of Pathology, Allama lqbal Medical College, Lahore, Pakistan. ${ }^{3}$ Citilab and Research Center, Lahore, Pakistan

\section{Received: 21 May 2018 Accepted: 5 October 2018}

Published online: 03 November 2018

\section{References}

1. Baran I, Aksu N. Phenotypic and genotypic characteristics of carbapenemresistant Enterobacteriaceae in a tertiary-level reference hospital in Turkey. Ann Clin Microbiol Antimicrob. 2016;15(1):20.

2. Khalifa $\mathrm{HO}$, et al. High carbapenem resistance in clinical gram-negative pathogens isolated in Egypt. Microb Drug Resist. 2017;23(7):838-44.

3. Mirsalehian A, et al. Determination of carbapenem resistance mechanism in clinical isolates of Pseudomonas aeruginosa isolated from burn patients, in Tehran, Iran. Journal of epidemiology and global health. 2017;7(3):155-9.

4. $\mathrm{Xu}$ Y, et al. Epidemiology of carbapenem resistant Enterobacteriaceae (CRE) during 2000-2012 in Asia. Journal of thoracic disease. 2015;7(3):376.

5. Satlin MJ, et al. Multicenter clinical and molecular epidemiological analysis of bacteremia due to carbapenem-resistant Enterobacteriaceae (CRE) in the CRE epicenter of the United States. Antimicrob Agents Chemother. 2017;61(4): e02349-16.

6. Wang, J.-T., et al., Carbapenem-nonsusceptible enterobacteriaceae in Taiwan. PLoS One, 2015. 10(3): p. e0121668.

7. Ye $Y$, et al. Mechanism for carbapenem resistance of clinical Enterobacteriaceae isolates. Experimental and Therapeutic Medicine. 2018;15(1):1143-9.

8. Dalmolin TV, et al. Detection and analysis of different interactions between resistance mechanisms and carbapenems in clinical isolates of Klebsiella pneumoniae. Braz J Microbiol. 2017;48(3):493-8.

9. Zafer $\mathrm{MM}$, et al. Antimicrobial resistance pattern and their beta-lactamase encoding genes among Pseudomonas aeruginosa strains isolated from cancer patients. Biomed Res Int. 2014:2014.

10. Iraz $\mathrm{M}$, et al. Distribution of $\beta$-lactamase genes among carbapenem-resistant Klebsiella pneumoniae strains isolated from patients in Turkey. Annals of laboratory medicine. 2015;35(6):595-601.

11. Yong $D$, et al. Characterization of a new metallo- $\beta$-lactamase gene, blaNDM1 , and a novel erythromycin esterase gene carried on a unique genetic structure in Klebsiella pneumoniae sequence type 14 from India. Antimicrob Agents Chemother. 2009:53(12):5046-54.

12. Bush K, Jacoby GA, Medeiros AA. A functional classification scheme for beta-lactamases and its correlation with molecular structure. Antimicrob Agents Chemother. 1995;39(6):1211

13. Walsh TR. Clinically significant carbapenemases: an update. Curr Opin Infect Dis. 2008;21(4):367-71.

14. Nordmann P, Poirel L. Emerging carbapenemases in gram-negative aerobes. Clin Microbiol Infect. 2002;8(6):321-31.
15. Haruta S, et al. Functional analysis of the active site of a metallo- $\beta$-lactamase proliferating in Japan. Antimicrob Agents Chemother. 2000;44(9):2304-9.

16. Ito $\mathrm{H}$, et al. Plasmid-mediated dissemination of the metallo-beta-lactamase gene blalMP among clinically isolated strains of Serratia marcescens. Antimicrob Agents Chemother. 1995;39(4):824-9.

17. Hawkey PM, et al. Occurrence of a new metallo- $\beta$-lactamase IMP-4 carried on a conjugative plasmid in Citrobacter youngae from the People's Republic of China. FEMS Microbiol Lett. 2001;194(1):53-7.

18. Hawkey P. Multidrug-resistant gram-negative bacteria: a product of globalization. J Hosp Infect. 2015;89(4):241-7.

19. Munita JM, Arias CA. Mechanisms of antibiotic resistance. Microbiology spectrum. 2016;4(2)

20. Scoulica EV, et al. Spread of Bla VIM-1-producing. E coli in a university hospital in Greece Genetic analysis of the integron carrying the bla VIM-1 metallo- $\beta$-lactamase gene Diagnostic microbiology and infectious disease. 2004;48(3):167-72

21. Cornaglia G, Giamarellou H, Rossolini GM. Metallo- $\beta$-lactamases: a last frontier for $\beta$-lactams? Lancet Infect Dis. 2011;11(5):381-93.

22. Kazmierczak, K.M., et al., Multi-year, multi-national survey of the incidence and global distribution of metallo- $\beta$-lactamase-producing Enterobacteriaceae and P. aeruginosa. Antimicrob Agents Chemother, 2015: p. AAC. 02379-15.

23. Rolain J, Parola P, Cornaglia G. New Delhi metallo-beta-lactamase (NDM-1): towards a new pandemia? Clin Microbiol Infect. 2010;16(12):1699-701.

24. Berrazeg $M$, et al. New Delhi Metallo-beta-lactamase around the world: an eReview using Google maps. Eurosurveillance. 2014;19(20):20809.

25. Pfeifer $Y$, et al. Molecular characterization of Bla NDM-1 in an Acinetobacter baumannii strain isolated in Germany in 2007. J Antimicrob Chemother. 2011;66(9):1998-2001.

26. Bonnin $\mathrm{R}$, et al. Dissemination of New Delhi metallo- $\beta$-lactamase-1producing Acinetobacter baumannii in Europe. Clin Microbiol Infect. 2012;18(9):E362-5.

27. Nakazawa Y, et al. A case of NDM-1-producing Acinetobacter baumanni transferred from India to Japan. J Infect Chemother. 2013:19(2):330-2.

28. Kumarasamy KK, et al. Emergence of a new antibiotic resistance mechanism in India, Pakistan, and the UK: a molecular, biological, and epidemiological study. Lancet Infect Dis. 2010;10(9):597-602.

29. Litzow JM, et al. High frequency of multidrug-resistant gram-negative rods in 2 neonatal intensive care units in the Philippines. Infection Control \& Hospital Epidemiology. 2009:30(6):543-9.

30. Le NK, et al. High prevalence of hospital-acquired infections caused by gram-negative carbapenem resistant strains in Vietnamese pediatric ICUs: a multi-Centre point prevalence survey. Medicine. 2016;95(27).

31. Bhat $V$, et al. Bacteriological profile and antibiotic susceptibility patterns of clinical isolates in a tertiary care cancer center. Indian journal of medical and paediatric oncology: official journal of Indian Society of Medical \& Paediatric Oncology. 2016;37(1):20.

32. Walther-Rasmussen J, Høiby N. OXA-type carbapenemases. J Antimicrob Chemother. 2006:57(3):373-83.

33. Bonnin RA, Poirel L, Nordmann P. AbaR-type transposon structures in Acinetobacter baumannii. J Antimicrob Chemother. 2011:67(1):234-6.

34. Khan $M$, et al. Emerging bacterial resistance patterns in febrile neutropenic patients: experience at a tertiary care hospital in Pakistan. JPMA. The Journal of the Pakistan Medical Association. 2004;54(7):357-60.

35. Irfan S, et al. Molecular and epidemiological characterisation of clinical isolates of carbapenemresistant Acinetobacter baumannii from public and private sector intensive care units in Karachi, Pakistan. J Hosp Infect. 2011;78(2):143-8.

36. Khan F, Khan A, Kazmi SU. Prevalence and susceptibility pattern of multi drug resistant clinical isolates of Pseudomonas aeruginosa in Karachi. Pakistan journal of medical sciences. 2014;30(5):951.

37. Kaleem F, et al. Frequency and susceptibility pattern of metallo-betalactamase producers in a hospital in Pakistan. The Journal of infection in developing countries. 2010;4(12):810-3.

38. Bauer $\mathrm{A}$, et al. Antibiotic susceptibility testing by a standardized single disk method. Am J Clin Pathol. 1966;45(4):493.

39. Wadekar MD, Anuradha K, Venkatesha D. Phenotypic detection of ESBL and MBL in clinical isolates of Enterobacteriaceae. Int J Current Res Acad Rev. 2013;1(3):89-5.

40. Kumar S, Mehra S. Performance of modified Hodge test and combined disc test for detection of Carbapenemases in clinical isolates of Enterobacteriaceae. Int J Curr Microbiol App Sci. 2015;4(5):255-61. 
41. Abrar S, et al. Distribution of CTX-M group I and group III $\beta$-lactamases produced by Escherichia coli and klebsiella pneumoniae in Lahore, Pakistan Microb Pathog. 2017;103:8-12.

42. Colom $\mathrm{K}$, et al. Simple and reliable multiplex PCR assay for detection of blaTEM, blaSHV and blaOXA-1 genes in Enterobacteriaceae. FEMS Microbiol Lett. 2003;223(2):147-51.

43. Shibata $\mathrm{N}$, et al. PCR typing of genetic determinants for metallo- $\beta$-lactamases and integrases carried by gram-negative bacteria isolated in Japan, with focus on the class 3 integron. J Clin Microbiol. 2003;41(12):5407-13.

44. Galani I, et al. First identification of an Escherichia coli clinical isolate producing both metallo- $\beta$-lactamase VIM-2 and extended-spectrum $\beta$-lactamase IBC-1. Clin Microbiol Infect. 2004;10(8):757-60.

45. Laxminarayan R, Bhutta ZA. Antimicrobial resistance-a threat to neonate survival. Lancet Glob Health. 2016;4(10):e676-7.

46. Sekar $\mathrm{R}$, et al. Carbapenem resistance in a rural part of southern India: Escherichia coli versus Klebsiella spp. Indian J Med Res. 2016;144(5):781.

47. Hu F-P, et al. Resistance trends among clinical isolates in China reported from CHINET surveillance of bacterial resistance, 2005-2014. Clin Microbiol Infect. 2016;22:S9-S14.

48. Ilyas $\mathrm{M}$, et al. Frequency, susceptibility and co-existence of MBL, ESBL \& AmpC positive Pseudomonas aeruginosa in tertiary care hospitals of Peshawar, KPK. In: Pakistan; 2015

49. Shan S, Sajid S, Ahmad K. Detection of Bla IMP gene in Metallo- $\beta$-lactamase producing isolates of imipenem resistant Pseudomonas aeruginosa; an alarming threat. Journal of Microbiology Research. 2015;5(6):175-80.

50. Shamim S, Abbas M, Qazi MH. Prevalence of multidrug resistant Acinetobacter baumannii in hospitalized patients in Lahore. Pakistan Pakistan J Mol Med. 2015;2(1):23-8.

51. Ameen $\mathrm{N}$, et al. Imipenem resistant Pseudomonas aeruginosa: the fall of the final quarterback. Pakistan journal of medical sciences. 2015;31(3):561.

52. Bashir $\mathrm{D}$, et al. Detection of metallo-beta-lactamase (MBL) producing Pseudomonas aeruginosa at a tertiary care hospital in Kashmir. Afr J Microbiol Res. 2011;5(2):164-72

53. Church D, et al. Burn wound infections. Clin Microbiol Rev. 2006;19(2):403-34.

54. AL-Aali KY. Microbial profile of burn wound infections in burn patients, Taif. Saudi Arabia Archives of Clinical Microbiology. 2016;7(2).

55. Anwar M, et al. Phenotypic detection of Metallo-Beta-lactamases in Carbapenem resistant Acinetobacter baumannii isolated from pediatric patients in Pakistan. Journal of pathogens. 2016:2016.

56. Nordmann P, Dortet L, Poirel L. Carbapenem resistance in Enterobacteriaceae: here is the storm! Trends Mol Med. 2012;18(5):263-72.

57. Safari $\mathrm{M}$, et al. Prevalence of ESBL and MBL encoding genes in Acinetobacter baumannii strains isolated from patients of intensive care units (ICU). Saudi journal of biological sciences. 2015;22(4):424-9.

58. García-Fernández A, et al. An ertapenem-resistant extended-spectrum- $\beta$ lactamase-producing Klebsiella pneumoniae clone carries a novel OmpK36 porin variant. Antimicrob Agents Chemother. 2010;54(10):4178-84.

Ready to submit your research? Choose BMC and benefit from:

- fast, convenient online submission

- thorough peer review by experienced researchers in your field

- rapid publication on acceptance

- support for research data, including large and complex data types

- gold Open Access which fosters wider collaboration and increased citations

- maximum visibility for your research: over $100 \mathrm{M}$ website views per year

At $\mathrm{BMC}$, research is always in progress.

Learn more biomedcentral.com/submissions 